KONRAD ŚWIDER

Instytut Studiów Politycznych PAN

\title{
Uwarunkowania trwałości obecnego systemu władzy w Rosji
}

\section{Determinants of the durability of the current system of power in Russia}

On March 18, 2018, on the fourth anniversary of the annexation of the Ukrainian Crimea, the incumbent President of the Russian Federation, Vladimir Putin, was elected for his fourth term - once again as the "non-alternative statesman". This choice is a peculiar monument to the durability of the current system of power in Russia. This article analyzes various factors and mechanisms constituting the foundation of the current Kremlin team's dominance in the political life of the Russian state. The process of consolidation of this elite in power began at the end of the 1990s - from the initiated by the administration of the previous Russian President Boris Yeltsin so-called project "Successor". The next stage was the consolidation of power by the secret service corporation represented by the new Russian leader - Federal Security Service. The foundations of durability of this authority was also its economic, foreign and historical policy, as well as attempts by the Kremlin to create an integral state ideology based on the concept of sovereign democracy as a factor of social mobilization and the one of main sources of legitimacy of political domination in Russia.

Keywords: Russia, Kremlin, power, policy, Federal Security Service, Vladimir Putin

Słowa kluczowe: Rosja, Kreml, władza, polityka, Federalna Służba Bezpieczeństwa, Władimir Putin

\section{Wprowadzenie}

18 marca 2018 r., w czwartą rocznicę anektowania przez Rosję ukraińskiego Krymu, urzędujący prezydent Federacji Rosyjskiej Władimir Putin został wybrany na czwartą kadencję. Po raz kolejny okazał się „bezalternatywnym mężem stanu", co jest dowodem trwałości obecnego systemu władzy w Rosji. Celem niniejszego artykułu jest prezentacja i analiza czynników i mechanizmów stanowiących fundament dominacji obecnej ekipy Kremla w życiu politycznym państwa rosyjskiego. 
Proces instalowania się putinowskiej elity jako nowej siły rządzącej Federacją Rosyjską rozpoczął się jeszcze pod koniec lat dziewięćdziesiątych XX w. - od tzw. projektu „Następca”, zainicjowanego przez administrację poprzedniego prezydenta Rosji, Borysa Jelcyna. Przedstawienie tej kwestii wydaje się istotne dla ukazania, że władza Władimira Putina jest konsekwencją ostrej walki politycznej w ówczesnej Rosji, w wyniku której zaistniały okoliczności pozwalające dyrektorowi Federalnej Służby Bezpieczeństwa (FSB) przejąć stery państwa. Najbardziej znany aspekt zdominowania rosyjskiej polityki przez oficerów średniego szczebla dawnego radzieckiego KGB, czyli druga wojna czeczeńska, jest wtórny wobec przesileń politycznych, do których dochodziło w tym kraju w ostatnich latach XX w. Kolejnym etapem przejmowania państwa przez postkagebowską elitę była konsolidacja władzy w rękach reprezentowanej przez nowego rosyjskiego przywódcę korporacji służb specjalnych - FSB. Podstaw trwałości tej władzy należy ponadto upatrywać w jej polityce gospodarczej, zagranicznej oraz historycznej, a także w podejmowanych przez Kreml próbach wypracowania integralnej ideologii państwowej w oparciu o koncepcję demokracji suwerennej jako czynnika mobilizacji społecznej i jednego z głównych źródeł legitymizacji politycznego panowania w Rosji. Nie bez znaczenia jest w tym kontekście rosyjska kultura polityczna, cechująca się m.in.:

- ugruntowaną w tradycji historycznej silną personalizacją władzy;

- mobilizacją społeczeństwa wokół centrali politycznej w trudnych momentach dziejowych ${ }^{1}$ (szczególnie gdy dowiodła wcześniej, że podjęła efektywne starania o poprawę sytuacji bytowo-materialnej obywateli);

- silnym poczuciem dumy narodowej (wzmacnianym inwokacjami do niej ze strony władz);

- wyraźną słabością opozycji, która często postrzegana jest w społeczeństwie jako agenturalna siła realizująca obce interesy (motor potencjalnej kolorowej rewolucji).

\section{Projekt „Następca”}

W latach dziewięćdziesiątych XX w. będąca głównym sukcesorem Związku Radzieckiego Rosja przechodziła pod kierunkiem reformatorskiego prezydenta Borysa Jelcyna dynamiczną transformację ustrojową. W spadku po ZSRR

1 Obecnie uchodzi za taki konflikt z Zachodem spowodowany polityką Kremla wobec Ukrainy i będąca jego konsekwencją zachodnia presja na Rosję. 
nowe państwo rosyjskie (Federacja Rosyjska) odziedziczyło jednak głęboki kryzys strukturalny, dostrzegalny przede wszystkim w gospodarce. Ceną radykalnych reform były liczne przesilenia polityczne i napięcia społeczne. Jelcyn z trudem sprawował swój urząd przez dwie kadencje, a pod koniec lat dziewięćdziesiątych pozycja schorowanego prezydenta była słaba. Zarówno on sam, jak i jego administracja rozpoczęli wobec tego intensywne, ale początkowo dyskretne poszukiwania następcy, który potrafiłby powstrzymać pełzającą dezintegrację państwa, mogącą skutkować jego rozpadem².

Jelcyn szukał osoby lojalnej, mającej odpowiednie zaplecze instytucjonalne i silną pozycję w którejś ze znaczących grup wpływu. Wybór padł na dyrektora FSB Władimira Putina, który już wcześniej zwracał na siebie uwagę jako sprawny urzędnik kremlowskiej administracji. Ostatecznie wizerunek i wartość polityczna Putina jako odpowiedniego sukcesora miały zostać zbudowane poprzez rozwiązanie reaktywującego się problemu czeczeńskiego. W marcu 1999 r., w związku z zaognieniem się sytuacji w rozdzieranej walkami klanowymi Czeczenii i na jej pograniczu, Jelcyn powierzył Putinowi stanowisko sekretarza Rady Bezpieczeństwa i zadanie uporania się z zaistniałym problemem.

W tym samym czasie północny Kaukaz, a w szczególności Dagestan, stał się obszarem coraz silniejszych ataków ekstremistów islamskich działających z terytorium Czeczenii. Kiedy sytuacja do tego dojrzała, zaniepokojony rosnącą aktywnością muzułmańskich terrorystów prezydent 9 sierpnia $1999 \mathrm{r}$. odwołał z funkcji p.o. premiera Siergieja Stiepaszyna i powierzył to stanowisko Władimirowi Putinowi, wyznaczając go wówczas nieoficjalnie na swojego następcę. Tę ostatnią decyzję rosyjski establishment uznał za absurd lub po prostu przejaw niepoczytalności chorego Jelcyna ${ }^{3}$. Mimo wszystko Putin wywarł na zobojętniałej wobec personalnych rozgrywek prezydenta Dumie pozytywne wrażenie i zyskał jej akceptację. Jelcyn wiedział, że nowy premier jest zdolnym do oparcia się politycznym naciskom pragmatykiem, co zademonstrował niegdyś wobec niezależnego od administracji prezydenckiej

2 Wiele przemyśleń zawartych w niniejszym artykule przedstawiłem w książce: K. Świder, Ewolucja elity władzy w Zwiazku Radzieckim i Rosji w kontekście przemian ideowych, politycznych, społecznych i ekonomicznych, Instytut Studiów Politycznych PAN, Warszawa 2013. O specyfice władzy Władimira Putina pisał prof. Józef Fiszer: J. Fiszer, Włodzimierz Putin - dlaczego zaufała mu cała Rosja? Specyficzne formy przywództwa politycznego, [w:] Przywództwo i elity polityczne w krajach WNP, red. T. Bodio, W. Jakubowski, Oficyna Wydawnicza ASPRA-JR, Warszawa 2010, s. 39-62.

3 Zob. R. Medvedev, Vladimir Putin: Četyre goda v Kremle, Vremâ, Moskva 2004, s. $66-67$. 
premiera Jewgienija Primakowa. Tymczasem krwawe akcje terrorystyczne przypisywane przez Kreml czeczeńskim separatystom spod znaku muzułmańskiego fundamentalizmu (wspieranym przez zewnętrzne radykalne islamskie organizacje terrorystyczne) zaczęły sięgać samej Moskwy, a do Dagestanu wtargnęły z Czeczenii duże oddziały muzułmańskich ekstremistów z zamiarem utworzenia tam republiki islamskiej ${ }^{4}$. Nie wszyscy komentatorzy podzielali oficjalną wersję interpretacji tych wydarzeń. Akty terroru, w których zginęło kilkaset osób, oraz starcia w Dagestanie postrzegano też jako prowokację z udziałem rosyjskich służb specjalnych (FSB), mającą posłużyć za pretekst do rozprawy z czeczeńskimi bojownikami ${ }^{5}$. Nowy szef rządu zapobiegł szerzeniu się paniki i bardzo sprawnie (medialnie) i zdecydowanie kierował kampanią antyterrorystyczną, której rezultatem było przywrócenie względnej kontroli Moskwy nad Czeczenią. W ciągu dwóch miesięcy stał się dzięki temu najpopularniejszym politykiem $\mathrm{w}$ kraju - z poparciem przekraczającym $70 \%{ }^{6}$. Druga wojna czeczeńska, trwająca do 2009 r., była rewanżem Kremla za porażkę Rosjan w pierwszej odsłonie konfliktu (1994-1996).

Znalezieniem właściwego następcy Borysa Jelcyna zainteresowana była również kremlowska „familia” (krąg najbliższych współpracowników prezydenta), która po kryzysie z 1998 r. znalazła się w trudnej sytuacji i szukała w swoich szeregach kandydata na nowego prezydenta, będącego bezkonkurencyjną alternatywą dla innych chętnych: byłych premierów Jewgienija Primakowa i Wiktora Czernomyrdina czy mera Moskwy Jurija Łużkowa. Za tymi postaciami kryły się siły gotowe odsunąć od władzy kremlowską kamarylę, która pod naciskiem prezydenta przekonywała się do osoby spoza swojego układu, jaką był Władimir Putin. Borysowi Jelcynowi imponował jego silny i niezależny charakter - jawił mu się jako osoba, która nie pozwoli na rozgrywanie się różnym grupom wpływu i jako przywódca ogromnego kraju nie będzie dryfowa$\mathfrak{ł a}^{7}$. Stawiając na tę osobę, pochodzący spoza stolicy Jelcyn ${ }^{8}$ dążył też do osła-

4 Zdaniem niektórych komentatorów inwazja terrorystów na Dagestan była reakcją czeczeńskich dowódców polowych na nominowanie Władimira Putina na premiera. G. Liparteliani, Prawda o Putinie. Polityczny kardiogram Rosji, przeł. M. Kotowska, Oficyna Wydawnicza Rytm, Warszawa 2001, s. 79-80.

5 Zob. A. Litwinienko, J. Felsztinski, Wysadzić Rosję, przeł. M. Szymański, Dom Wydawniczy Rebis, Poznań 2007.

6 V. Sogrin, Političeskaâ istoriâ sovremennoj Rossii. 1985-2001. Ot Gorbačeva do Putina, Ifra-M-Ves' mir, Moskva 2001, s. 223.

7 A. Bunič, Osen' oligarhov. Istoriâ prihvatizacii i buduŝsee Rossii, Èksmo, Moskva 2005, s. 393.

8 Borys Jelcyn urodził się we wsi Butka w obwodzie swierdłowskim na Uralu, a w przyszłości stał się prominentnym działaczem partii komunistycznej w Swierdłowsku (obecnie Jekaterynburg), skąd trafił do Moskwy. 
bienia w strukturach władzy układu moskiewskiego, a reprezentujący klany petersburskie Putin doskonale się do tego nadawał. Ostatecznie przeprowadzony przez „kolektywnego Jelcyna” projekt „Następca” nie uzyskał poparcia jedynie grupy moskiewskiej". 31 grudnia 1999 r. Borys Jelcyn zrezygnował z urzędu prezydenta Federacji Rosyjskiej i przekazał obowiązki Władimirowi Putinowi, który trzy miesiące później, w marcu 2000 r. wygrał wybory prezydenckie już w pierwszej turze ${ }^{10}$.

Oczywiście Jelcyn, wyznaczając Putina na swojego następcę, nie kierował się wyłącznie względami personalnymi. Faworyt pierwszego prezydenta Rosji reprezentował środowisko służb specjalnych, pełniąc funkcję szefa FSB. W ulegającym destabilizacji państwie korporacja FSB była jednym z nielicznych organów władzy federalnej, który zachował pionowe struktury we wszystkich regionach federacji i jednocześnie scentralizowane zarządzanie $^{11}$. Podejmowane już wcześniej próby podporządkowania terytorialnych jednostek FSB lokalnym ośrodkom władzy zostały storpedowane, co sprawiło, że kontrwywiad pozostał (i wciąż pozostaje) obok armii istotnym czynnikiem jedności państwa rosyjskiego. Pod wpływem powstałej na bazie KGB Federalnej Służby Bezpieczeństwa rosyjska elita uległa procesowi militaryzacji i sowietyzacji, przekształcając się w militokrację, tj. rządy resortów siłowych cementowane przez korporacyjnego ducha służb specjalnych $^{12}$. Militokratyczna elita stanowi wspólnotę, w której obowiązuje szczególnie silna lojalność i solidarność branżowa. Stworzone przez nią mechanizmy władzy są podwójnie trwałe, gdyż wzmacnia je ideologia patriotyzmu rozrzedzonego liberalnymi ideami ekonomicznymi ${ }^{13}$. Czynniki te zdeterminowały nową klanowości reżimu Władimira Putina.

9 B. Mazo, Piterskie protiv moskovskih, ili kto est' kto v okruženii V.V. Putina, Èksmo-Algoritm, Moskva 2003, s. 379.

10 Opozycyjni politolodzy i publicyści Jurij Fielsztinskij i Władimir Pribyłowskij zakwestionowali wiarygodność wyników wyborów prezydenckich z 2000 r. i kolejnych z 2004 r. Według ich szacunków, gdyby w 2000 r. nie doszło do fałszerstw, Putin uzyskałby w pierwszej turze 48-49\% głosów, co skazałoby go rywalizację w drugiej rundzie. W 2004 r. jego zwycięstwo w pierwszej turze było natomiast przesądzone, ale manipulowano ich zdaniem przy frekwencji, zawyżając ją w skali całego kraju o 10-15\% (oficjalnie wyniosła $64,39 \%$ ), a w autonomicznych republikach narodowych - nawet o $30-40 \%$, przez co osiągnęła tam ona typowo radziecki poziom ponad 90\%. J. Felsztinski, W. Pribyłowski, Korporacja zabójców. Rosja, KGB i prezydent Putin, przeł. C. Murawski, posł. opatrzył W. Marciniak, Prószyński i S-ka, Warszawa 2008, s. 129-146, 351-356.

11 A. Grajewski, Tarcza i miecz. Rosyjskie stużby specjalne 1991-1998, Biblioteka „Więzi”, Warszawa 1998, s. 327.

12 O. Kryštanovskaâ, Anatomiâ rossijskoj èlity, Zaharov, Moskva 2004, s. 264-286.

13 Tamże, s. 284. 
Utrwaloną historycznie cechą władzy w Rosji jest jej silna personalizacja (kojarzenie z konkretną osobą pełniącą najwyższe funkcje państwowe). Rządy Putina wpisują się w ten model, jednak w literaturze i publicystyce można spotkać poglądy, że obecny prezydent Rosji jest jedynie projektem, twarzą czy też logo władzy, w istocie będąc „kolektywnym Putinem” i wykonawcą woli korporacji ${ }^{14}$. W rezultacie projektu „Następca” najwyższa władza w Rosji stała się domeną funkcjonariuszy średniego i wysokiego szczebla (lecz nie najwyższego) dawnych radzieckich służb specjalnych. FSB jako zreorganizowana i zmodernizowana korporacja przystąpiła do akcji stabilizowania kraju według logiki korporacyjnej.

Za systemem personifikowanym przez drugiego prezydenta Rosji przemawia rozpowszechniany przez pracowników służby bezpieczeństwa pogląd, że to ludzie związani z dawnym KGB wyciągają Rosję z przepaści, w którą wpadła po 1991 r. Generał Wiktor Czerkiesow - w przeszłości naczelny leningradzko-petersburski kagebista, obecnie znajdujący się w otoczeniu Władimira Putina - ukuł nawet zgrabną (a według niektórych ponurą) metaforę: po upadku ZSRR kraj przez lata pikował w przepaść bez dna, a jedynym, co zapobiegło kompletnej katastrofie, był czekistowski hak, na którym Rosja zawisła jak alpinista, który odpadł ze ściany ${ }^{15}$. Następca Putina na stanowisku dyrektora FSB, generał Nikołaj Patruszew, stwierdził z kolei, że funkcjonariusze byłego KGB to zakon rycerski i szlachta współczesnej Rosji - jedyna zdrowa moralna siła zdolna podnieść z upadku pogrążony w zamęcie kraj ${ }^{16}$.

\section{Konsolidacja władzy}

Kluczowym historycznym problemem Rosji jest zbieranie władzy i ziemi, co można określić jako konsolidację państwa. Aby tego dokonać, należało: ponownie podporządkować Kremlowi parlament, „spacyfikować” regiony, subordynować oligarchię, kontrolować branżowe grupy interesów i kanały finansowe. Wiosną 2000 r. powołano liberalno-prorynkowy rząd, którego ministrów cechowały średnia wieku poniżej 45 lat i petersburskie (leningradzkie) pochodzenie $^{17}$. Wkrótce miało się jednak okazać, że zarówno rząd, jak i cały rosyjski reżim są niedefiniowalne w kategoriach ideologicznych, które miały

14 J. Felsztinski, W. Pribyłowski, Korporacja..., s. 9; B. Reitschuster, Władimir Putin. Doką prowadzi Rosję?, przeł. M. Zeller, Bertelsmann Media, Warszawa 2005, s. 270-271.

15 Zob. W. Radziwinowicz, Wyuczony czekista, „Gazeta Wyborcza”, 29.12.2009.

16 Zob. tamże.

17 Zob. B. Mazo, Piterskie...; A. Muhin, Putin. Bližnij krug prezidenta, Algoritm, Moskva 2005. 
być co najwyżej instrumentalnie wykorzystywane do umacniania państwa. Młody i energiczny gabinet Michaiła Kasjanowa w liberalnym tempie i z liberalną niechęcią do wikłania się w czasochłonne rozgrywki i spory między różnymi grupami interesów przystępował do ewidencji materiałowych zasobów władzy oraz kanałów ich redystrybucji. Administracja Kremla określiła trzy priorytety polityki wewnętrznej: reorganizację państwa, przewidującą wzmocnienie centrum i pionowej struktury władzy; stworzenie nowego modelu relacji państwa i elit biznesowych, który gwarantowałby odsunięcie oligarchów od ośrodków władzy politycznej; wprowadzenie do polityki gospodarczej i społecznej zmodyfikowanych zasad liberalno-rynkowych ${ }^{18}$. Władimir Putin przystąpił do konsolidacji systemu władzy, uznawszy, że Rosja dryfuje od modelu państwa federacyjnego do zdecentralizowanego ${ }^{19}$. Zreorganizował zatem ustanowioną przez Jelcyna instytucję pełnomocnych przedstawicieli prezydenta, którzy mieli za zadanie monitorować i koordynować działalność instytucji i urzędów na szczeblu regionalnym, głównie w zakresie wykorzystywania funduszy państwowych. Podzielono w tym celu terytorium Rosji na siedem okręgów federalnych, które w dużej mierze pokrywały się z okręgami wojskowymi. Była to próba integrowania i konsolidowania państwa według zasad logistyki wojskowej, jednak bez militarystycznych treści ${ }^{20}$. Za zabezpieczenie wdrażania reform wzmacniających Rosję miały odpowiadać FSB i Prokuratura Generalna; w regionach zorganizowano delegatury FSB, MSW, prokuratury i służb podatkowych, które podlegały wyłącznie centrum.

Namiestnikami okręgów federalnych - czyli pełnomocnymi przedstawicielami prezydenta, którzy weszli ponadto w skład Rady Bezpieczeństwa Władimir Putin mianował generałów z armii i FSB. Pośrednim celem tych działań było ograniczenie wpływów regionalnych przywódców (prezydentów republik i gubernatorów), będących dotychczas członkami wyższej izby parlamentu - Rady Federacji. Po zreformowaniu tego ciała mogli w nim zasiadać jedynie niżsi rangą przedstawiciele władz regionalnych - często $\mathrm{z}$ rekomendacji Kremla. Aby zneutralizować niezadowolenie przywódców regionów, zrzeszono ich w organie doradczym - Radzie Państwowej i wydłużono możliwość sprawowania urzędu z dwóch do czterech kadencji. Poprzez degradację statusu

18 Zob. V. Sogrin, Političeskaâ istoriâ..., s. 240.

19 A. Skrzypek, Druga smuta. Zarys dziejów Rosji 1985-2004, Oficyna Wydawnicza ASPRA-JR, Warszawa 2004, s. 150.

20 Zob. J. Staniszkis, Postkomunizm. Próba opisu, Słowo/Obraz Terytoria, Gdańsk 2001, s. 161; taż, Postkomunistyczne państwo: w poszukiwaniu tożsamości, Instytut Spraw Publicznych, Warszawa 2000, s. 6; taż, Antropologia władzy. Między Traktatem Lizbońskim a kryzysem, Prószyński i S-ka, Warszawa 2009, s. 169. 
politycznego regionalnych liderów Kremlowi udało się zasymilować gubernatorskie ugrupowanie w Dumie - Ojczyznę. W rezultacie inkorporowania jej do obozu prezydenckiego oraz połączenia z prokremlowską Jednością powstała nowa, wzmocniona partia władzy - Jedna Rosja, która w przyszłości zdecydowanie będzie wygrywać wszystkie wybory parlamentarne. Należy wspomnieć, że Władimir Putin miał już spore doświadczenie w powstrzymywaniu tendencji odśrodkowych, gdyż intensywnie zajmował się tym w latach 1997-1998, pełniąc funkcję szefa departamentu kontroli Administracji Prezydenta Federacji Rosyjskiej, i nabył wówczas odpowiednią wiedzę prewencyjną ${ }^{21}$.

Po podporządkowaniu regionów działania Kremla mające na celu wzmocnienie państwa zostały wymierzone w oligarchię finansową, która w końcowym okresie prezydentury Borysa Jelcyna zdobyła ogromne wpływy w najwyższych rosyjskich instytucjach. Instytucjonalno-personalne odseparowanie koncentrujących i rozgrywających swoje interesy w Moskwie oligarchów od naczelnych organów władzy miało polegać przede wszystkim na zmianie relacji wielkiego biznesu z prowincją, czyli regionalizacji grup finansowych ${ }^{22}$. Dotychczas oligarchia przejawiała wobec regionów stosunek niemal kolonialny, eksploatatorski, a teraz miała tam zostać zesłana. W strategii Kremla administracyjne wypędzenie jej ze stolicy i przesunięcie na prowincję redukowało też zdolność oddziaływania na centrum ze strony gubernatorów, gdyż zrzucało im na głowy potężnych rywali lokalnych. Nie wszyscy oligarchowie godzili się z rolą wyznaczoną im przez Władimira Putina, ale jego zmaganiom z plutokracją - identyfikowaną z patologicznymi, korupcyjno-kleptokratycznymi metodami akumulacji kapitału - towarzyszył aplauz społeczny. Wojna, jaka wywiązała się między prywatnymi mediami oligarchów a reżimowymi środkami przekazu, zdeterminowała Kreml do szybkiej rozprawy $\mathrm{z}$ tą grupą społeczną. Najczęściej oskarżano ich o nadużycia przy prywatyzacji - głównie przejmowanie za bezcen intratnych przedsiębiorstw państwowych. W ten sposób formułowano zarzuty wobec najważniejszych oligarchów epoki jelcynowskiej: Borysa Bieriezowskiego, Władimira Gusinskiego, Władimira Potanina i Wagita Alekpierowa, a także niezależnego, lecz mającego wielkie ambicje polityczne Michaiła Chodorkowskiego ${ }^{23}$. Organy kontroli i ścigania starały się wykazywać długi oligarchii i przejmować jej aktywa.

21 Zob. A. Furier, Dekada Jelcyna. Uwarunkowania rosyjskich przemian spolecznych i politycznych 1991-2000, Wydawnictwo Naukowe US, Szczecin 2003, s. 258.

22 Zob. A. Skrzypek, Druga smuta..., s. 154.

23 Zob. R. Miedwiediew, Władza i biznes w nowej Rosji, „Dziś. Przegląd Społeczny” 2004, nr 1, s. 51-62. 
Znacjonalizowano tak np. koncern medialny Gusinskiego (Media-Most), co spotkało się z ostrą krytyką zachodnich mediów, wietrzących w działaniach Kremla zamach na wolność słowa. Chcąc uniknąć więzienia, niektórzy oligarchowie, jak Bieriezowskij czy Gusinskij, wyemigrowali za granicę, co rosyjska opinia publiczna przyjęła z niechętną im obojętnością (być może z uwagi na ich żydowskie pochodzenie i wynikające stąd uprzedzenia). Walka z plutokracją trwała $\mathrm{z}$ różnym natężeniem przez całą pierwszą kadencję Putina. Kulminacją tych działań było aresztowanie pod koniec października $2003 \mathrm{r}$. ostatniego z krnąbrnych oligarchów - Michaiła Chodorkowskiego, a następnie pokazowy proces sądowy i skazanie go w 2005 r. na osiem lat kolonii karnej. Przeciwko takim metodom rozprawiania się z oponentami Kremla wystąpił premier Michaił Kasjanow (w przyszłości jeden z liderów antykremlowskiej opozycji), co stało się jedną z głównych przyczyn zdymisjonowania jego gabinetu przez Władimira Putina w lutym 2004 r.

Subordynowanie oligarchii stanowiło obok wyparcia z Moskwy gubernatorów ważny krok nowej kremlowskiej elity w rozwiązaniu fundamentalnego wówczas problemu Rosji, jakim była konsolidacja władzy. Ten ostatni aspekt, niezależnie od metod i środków stosowanych w celu umocnienia państwa a postrzeganych $\mathrm{w}$ istotnym dla Zachodu, a drugorzędnym w Rosji kontekście ich zgodności lub sprzeczności z zasadami demokracji - wydaje się słabo rozumiany na Zachodzie (w tym w Polsce). Demokracja w zachodniej percepcji ma wymiar aksjologiczny, natomiast w rosyjskiej - instrumentalny.

Na tym etapie konsolidacji władzy przez putinowski Kreml nastąpiła więc wymiana korporacji, która ją sprawowała, ale nie kontrolowała państwa: jelcynowskich ekonomistów żyjących w symbiozie z kastą oligarchów zastąpili ludzie związani z obecnymi i radzieckimi służbami specjalnymi. Byli to z reguły dawni pracownicy KGB średniego szczebla (z tzw. pokolenia pułkowników), odczuwający niechęć lub nawet pogardę wobec komunistycznej generalicji, która z obojętnością przyglądała się rozpadowi supermocarstwa. Będąc pragmatykami, nie tęsknili oni za ZSRR jako formą państwa, ale za blaskiem i siłą przyciągania radzieckiego imperium - za jego prestiżem i splendorem, choć rozumieli, że Federacja Rosyjska nie jest supermocarstwem ${ }^{24}$. Rządy puł-

24 I. Krastev, Suwerenna demokracja. Nowa rosyjska ideologia, „Europa - Tygodnik Idei”, [dodatek do:] „Dziennik”, 26.08.2007; „Europa”, [dodatek do:] „Newsweek Polska”, 26.08.2007. Choć Władimir Putin w kontekście swojej wizji polityki Rosji wobec Stanów Zjednoczonych przyznawał, że nie jest już ona supermocarstwem (zob. A. Skrzypek, Druga smuta..., s. 161), to zatwierdzona przez niego 28.07.2000 r. 'Koncepcja polityki zagranicznej Federacji Rosyjskiej' określała ją jako wielkie mocarstwo (wielikaja dierżawa). Koncepciâ vnešnej politiki Rossijskoj Federacii, „Diplomatičeskij vestnik” 2000, № 8. 
kowników odznaczały się wysoką, niemal rewolucyjną dynamiką początkową, by z czasem stać się bastionami konserwatyzmu. W Rosji początku XXI w. nie byli to jednak oficerowie armii, co przywodziłoby na myśl juntę wojskową, ale daleko bardziej wyrafinowanej korporacji - tajnych służb.

Konsolidacja czy też zbieranie władzy i państwa prowadzone było na kilku przenikających się płaszczyznach: politycznej, ekonomicznej i społecznej. Korporacja kagebeszników dobrze rozumiała, że umocnienie podstawy swojej władzy i uniezależnienie się od nacisków ze strony innych korporacji czy grup branżowo-produkcyjnych (np. kompleksów: wojskowo-przemysłowego, paliwowo-energetycznego, agrarno-przemysłowego) wymaga sprawowania kontroli nad strategicznymi gałęziami gospodarki i kanałami redystrybucji środków budżetowych - temu przecież służyło subordynowanie gubernatorów i oligarchów. Oczywiście nie stosowano przy tym metod bolszewickich, tzn. nie czyszczono instytucji do fundamentów i nie anihilowano ich. Oligarchię pozostawiono jako osobliwą dekorację, a poprzez jej etatyzację i zobowiązanie do lojalności stworzono niejako rejestr oligarchów - swoistą korporacyjną rezerwę menadżerską. W czasie pierwszej kadencji Władimira Putina dawni radzieccy kagebiści i siłowicy (tj. pracownicy MSW i armii) zdołali przejąć 2,5 tys. stanowisk decyzyjnych w administracji centralnej (10-70\% korpusu urzędniczego, zależnie od instytucji i szczebla), uzyskując kontrolę nad skarbem państwa, milicją, służbą podatkową, celną, antynarkotykową, centralami handlu bronią czy nawet państwowymi liniami lotniczymi ${ }^{25}$. Już w latach dziewięćdziesiątych XX w. kontrolę nad najważniejszymi instytucjami państwa rosyjskiego systematycznie przejmowali działający na marginesie głównych wydarzeń funkcjonariusze aktywnej rezerwy $^{26}$, którzy stanowili zorganizowaną strukturę w ramach tzw. firmy (korporacji) i po odejściu $\mathrm{z}$ etatów $\mathrm{w} \mathrm{KGB} / \mathrm{FSB}$ delegowani byli na posady cywilne lub wojskowe ${ }^{27}$.

Władimir Putin chętniej obsadzał resorty korporacyjnymi menadżerami niż kompetentnymi specjalistami, ponieważ rosyjskie ministerstwa pełniły funkcję kanałów redystrybucji dóbr, a do najważniejszych zadań ministrów należała surowa kontrola strumieni finansowych w dziedzinach przyporządkowanych poszczególnym resortom. Miarą kompetencji urzędników stało się więc pochodzenie z odpowiednich organów, a pożądanymi

25 O. Kryštanovskaâ, Anatomiâ..., s. 283; I. Miecik, Gwardia Putina, „Polityka”, 20.08.2005.

26 Sformułowanie $\mathrm{z}$ terminologii tajnych służb funkcjonujące od czasów Jurija Andropowa.

27 J. Felsztinski, W. Pribyłowski, Korporacja..., s. 22-24. 
kompetencjami - lojalność i korporacyjny management ${ }^{28}$. Administracja Władimira Putina zorganizowała się w sprawny kapitalistyczno-etatystyczny zarząd, ale odpowiednie podstawy do tego zostały stworzone jeszcze w epoce jelcynowskiej. Reżim Putina nadał arbitralnemu rozdawaniu i cofaniu koncesji na poszczególne fragmenty majątku państwowego moc obowiązującego prawa. Zwiększona władza Kremla w tym zakresie manifestowała się na przykład tak, że jednym podmiotom anulowano zadłużenie, a innym odbierano za długi majątek.

Jednym z symptomów konsolidacji władzy w Rosji przez korporację FSB była dokonana przez Dumę w listopadzie 2008 r. zmiana konstytucyjnych zapisów o czasie trwania kadencji prezydenta. Wydłużono ją z czterech do sześciu lat, stąd okresy kolejnych kadencji to lata 2012-2018 i 2018-2024.

\section{Gospodarka}

Władimir Putin rozpoczynał swoją prezydenturę pod szczęśliwą gwiazdą. Rosyjska gospodarka szybko wydobywała się z kryzysu roku 1998, a na świecie zaczynał się boom naftowo-gazowy, co sprzyjało wpływom do budżetu państwa, gdyż większość z nich pochodziła z eksportu surowców energetycznych. Rosyjskie społeczeństwo, mocno odczuwające jeszcze skutki kryzysu finansowego i zniechęcone permanentną wojną na górze, pragnęło stabilizacji. Pierwsze dwie czteroletnie kadencje Władimira Putina, a nawet prezydentura Dmitrija Miedwiediewa (na którą przypadł globalny kryzys roku 2008) upłynęły pod znakiem dynamicznego wzrostu gospodarczego i gromadzenia przez Rosję potężnych rezerw walutowych, sięgających ok. $500 \mathrm{mld}$ dol. W latach 1999-2012 PKB Rosji zwiększył się prawie pięciokrotnie, co pozwoliło budżetowi odzyskać płynność i przyczyniło się do szybkiej poprawy poziomu życia mieszkańców kraju.

Najbardziej wymiernym wynikającym z tego sukcesem było poparcie społeczne dla kremlowskiego reżimu, które nie spadało poniżej 70\%. Rosja stawała się krajem społecznego solidaryzmu w wersji etatystycznej ${ }^{29}$. Podczas swoich pierwszych kadencji Putin starał się realizować najbardziej miękki z możliwych wariantów rozwoju Rosji, a cała jego polityka nastawiona była

28 Zob. S. Biełkowski, Biznes Władimira Putina. Zakończenie, [w:] Imperium Putina, red. W. Konończuk, Fundacja im. Stefana Batorego, Warszawa 2007, s. 59-72; B. Mazo, Piterskie..., s. 380.

29 A. Walicki, Odpowiedź Michnikowi, „Gazeta Wyborcza”, 12-13.01.2008. 
na organiczne i stopniowe regulowanie sprzeczności epoki Jelcyna ${ }^{30}$. W powszechnym odbiorze społecznym poprawa sytuacji ekonomicznej w kraju wiązała się z wyeliminowaniem przez Kreml kleptokracji oligarchów, a Władimir Putin jawił się jako polityk, który „zrobił porządek ze złodziejami”.

Obecnie Rosja za swoje agresywne działania na Ukrainie (aneksję Krymu i wspieranie separatystów w Donbasie) objęta jest międzynarodowymi sankcjami gospodarczymi. Nie wpływają one jednak znacząco na ewentualny spadek poparcia społecznego dla Kremla. Rosjanie cierpliwie znoszą recesję i sankcje, traktując je zgodnie z przekazem Kremla jako cenę, którą ich kraj płaci za suwerenną politykę międzynarodową i niewygodną dla Zachodu (szczególnie USA) realizację swoich interesów geopolitycznych. Sankcje ekonomiczne, których doświadcza Federacja Rosyjska, niewątpliwie są odczuwalne, co przejawia się w znaczącym spadku wskaźników makroekonomicznych oraz utrudnionym dostępie do zachodniego know-how, zwłaszcza w zakresie technologii usprawniających wydobycie ropy naftowej i gazu ziemnego z głębokich pokładów. Rosyjska odpowiedź na sankcje - wstrzymanie importu produktów rolnych i artykułów spożywczych z Zachodu - zmusiła władze państwowe do rozwoju zaniedbanego rolnictwa w ramach strategii bezpieczeństwa żywnościowego kraju. Oficjalna propaganda przedstawiła to jako sukces gospodarczy państwa w warunkach wieloletniej wojny ekonomicznej narzuconej przez czynniki zewnętrzne.

\section{Geopolityka i polityka zagraniczna}

Geopolityka jest w Rosji dziedziną o szczególnym znaczeniu, zwłaszcza w okresie przełomów dziejowych (jak rozpad ZSRR), gdyż służy łagodzeniu postimperialnej traumy, racjonalizacji nowych (pozimnowojennych) uwarunkowań w systemie międzynarodowym i kreowaniu dla państwa nowych perspektyw historiozoficznych (wyzwań i misji dziejowych), stając się elementem kultury akademickiej i strategicznej ${ }^{31}$. W Federacji Rosyjskiej

30 Rosja. XX wiek. Od utopii komunistycznej do rzeczywistości globalistycznej, red. J. Zołotowskij, przeł. P. Burek, Wydawnictwo Uniwersytetu Jagiellońskiego, Kraków 2004, s. 170.

31 Szerzej na temat różnych aspektów teoretycznych rosyjskiej geopolityki zob. m.in.: K. Świder, Geopolityka jako ,,światopoglad władzy w Rosji”, „Studia Polityczne” 2017, nr 1, s. 107-131; tenże, Osobliwości metodologiczne rosyjskiej geopolityki, „Myśl Ekonomiczna i Polityczna” 2016, nr 4, s. 220-239; J. Staniszkis, W. Marciniak, K. Świder, Sekularyzacja myślenia politycznego w Rosji. Przejście od religijnej idei „właściwego istnienia" do koncepcji imperium i geopolityki, Instytut Studiów Politycznych PAN, Warszawa 2016, s. 123-190. 
geopolityka przechodziła przez trzy zasadnicze etapy: konceptualizacji, ideologizacji i doktrynalizacji, przekształcając się w postmodernistyczny dyskurs imperialny wyposażony w nowoczesny aparat pojęciowy (choć nierzadko niespójny i pseudointelektualny - jak np. u Aleksandra Dugina, głównego ideologa neoeurazjatyckiego nurtu rosyjskiej geopolityki). Myślenie geopolityczne, oficjalnie odcinające się od skrajnych poglądów, stało się istotnym elementem retorycznego instrumentarium Kremla oraz strategii koncepcyjnych rosyjskiej polityki zagranicznej.

Nowa kremlowska administracja starała się nie kontynuować charakterystycznego dla rosyjskiej polityki zagranicznej drugiej połowy lat dziewięćdziesiątych XX w. konfrontacyjnego dyskursu z Zachodem. Rosyjska dyplomacja podejmowała wysiłki na rzecz ocieplenia relacji ze Stanami Zjednoczonymi i Unią Europejską. Stosunki z Waszyngtonem szczególnie szybko poprawiały się po ataku terrorystycznym na World Trade Center we wrześniu 2001 r., gdy Władimir Putin solidaryzował się z prezydentem George'em W. Bushem. Wykorzystał to później taktycznie, dyskredytując w kontekście międzynarodowego terroryzmu czeczeński ruch separatystyczny. Rosyjskie władze nie zdołały jednak zdyskontować amerykańskiej tragedii w pełni. Waszyngton tak jak dawniej - nie przystał na propozycję Moskwy, by w zamian za rosyjskie uznanie dominacji USA na świecie przyznać Rosji status specjalnego globalnego sojusznika i uznać jej szczególną rolę na obszarze postradzieckim. Kreml zaczął więc prowadzić wobec Białego Domu asertywną politykę, co przejawiało się w zbliżeniu z Chinami i Indiami (zwłaszcza w zakresie współpracy wojskowej), zwiększeniu presji surowcowo-energetycznej na byłe republiki radzieckie i ekspansji gazowej w Europie, a także w samodzielnych i sprzecznych z polityką Stanów Zjednoczonych działaniach na Bliskim Wschodzie - m.in. uznaniu palestyńskiego Hamasu czy odrzuceniu amerykańskich planów wobec Iranu ${ }^{32}$. W polityce Rosji wobec krajów Wspólnoty Niepodległych Państw (WNP) obowiązywała natomiast podwójna strategia: z jednej strony (przynajmniej w oficjalnych deklaracjach) wspieranie inicjatyw i dążeń reintegracyjnych w przestrzeni postradzieckiej, z drugiej jednak pragmatyczne egzekwowanie zadłużenia $\mathrm{z}$ tytułu dostaw nośników energii i przypominanie sąsiadom o zależności energetycznej, a więc szantaż energetyczny. W oficjalnych komentarzach dotyczących sytuacji międzynarodowej unikano konfrontacyjnej retoryki. Stosowane w epoce radzieckiej mało

32 Zob. A. Bryc, Rosja w XXI wieku. Gracz światowy czy koniec gry?, Wydawnictwa Akademickie i Profesjonalne, Warszawa 2008, s. 217. 
dyplomatyczne określenia typu wróg czy przeciwnik zastępowano łagodniejszymi, w rodzaju konkurent, a w ostateczności rywal. Kreml tradycyjnie lansował policentryczny model systemu międzynarodowego, dążąc do wzmocnienia prerogatyw i rangi Organizacji Narodów Zjednoczonych, a zwłaszcza jej Rady Bezpieczeństwa. Na Zachodzie często interpretowano to jako zamiar restauracji koncertu mocarstw.

Stosunki między Moskwą a Waszyngtonem zaczęły się szybko psuć po amerykańskiej agresji na Irak w marcu 2003 r. Moskwa potępiła ją, chociaż wcześniej, po zamachu na WTC, poparła inwazję Stanów Zjednoczonych na Afganistan. Prawdziwy kryzys w relacjach rosyjsko-amerykańskich nastąpił jednak dopiero w czasie wspieranych przez USA kolorowych rewolucji - w Gruzji, a zwłaszcza na Ukrainie. Na Kremlu odbierano je jako swego rodzaju próbę generalną przed potencjalnym sterowanym z Zachodu przewrotem w Rosji ${ }^{33}$. Rysowany przed społeczeństwem obraz zachodnich dążeń do ponownego narzucenia państwu rosyjskiemu systemu neoliberalnego, skompromitowanego w epoce Jelcyna - co wyraźnie eksponowano w kremlowskiej retoryce - skutecznie integrował je z władzą.

W polityce zagranicznej, mimo oficjalnie propagowanej koncepcji sojuszu strategicznego z Chinami, Indiami i Iranem, Moskwa zaczęła de facto stosować strategię samotnego wilka ${ }^{34}$. Świadczy o tym dokonana w latach 2006-2007 rewizja dotychczasowych założeń polityki zagranicznej, potwierdzona następnie w asertywnym wystąpieniu rosyjskiego prezydenta 10 lutego 2007 r. na 43 Monachijskiej Konferencji Bezpieczeństwa. Władimir Putin domagał się tam respektowania przez Stany Zjednoczone rosyjskich interesów i równorzędnego traktowania głosów Waszyngtonu i Moskwy w sprawach decydujących o porządku międzynarodowym; wyznaczył też Zachodowi czerwoną linię na obszarze postradzieckim. Rosja dowiodła swojej determinacji w czasie krótkiej zwycięskiej inwazji na Gruzję w sierpniu 2008 r., a w przyszłości miała ją potwierdzić po wspieranej przez USA i Unię Europejską rewolucji godności na Ukrainie z końca 2013 r., anektując Krym i wspierając prorosyjski separatyzm w Donbasie. Po wojnie w Gruzji Moskwa odniosła konkretne, ale być może tylko doraźne sukcesy na arenie międzynarodowej, np. zahamowanie wzrostu amerykańskich wpływów na obszarze postradzieckim, powstrzymanie procesu rozszerzania NATO na wschód czy

33 Zob. A. von Rétyi, George Soros. Multimiliarder, jego globalna sieć i koniec takiego świata, jaki znamy, przeł. E. Lubelska, Biały Kruk, Kraków 2016, s. 178-208.

34 Zob. M. Stuermer, Putin i odrodzenie Rosji, przeł. B. Madejski, Wydawnictwo Dolnośląskie, Wrocław 2010, s. 176, 192, 195-197. 
też tymczasową rezygnację Waszyngtonu z budowy tarczy antyrakietowej w Polsce i Czechach ${ }^{35}$. Posłużyły one Kremlowi do budowania w oczach społeczeństwa wizerunku państwa rosyjskiego jako szanowanego i wpływowego. Zarówno w polityce wewnętrznej, jak i międzynarodowej dąży on do wykreowania nowego wizerunku Rosji jako w pełni samodzielnego podmiotu stosunków międzynarodowych, mającego istotny głos w kwestiach o zasięgu i znaczeniu globalnym, a także status wielkiego mocarstwa. Zachód, który próbowano naśladować we wczesnych latach epoki Jelcyna, przestał być atrakcyjny zarówno dla narodu, jak i dla polityków ${ }^{36}$.

Za główny cel swojego oddziaływania geopolitycznego i geostrategicznego putinowska Rosja uznaje obszar postradziecki (WNP), a szczególnie te jego kraje, z którymi graniczy. Działania Kremla są tu elementem polityki wewnętrznej, co spotyka się ze społeczną akceptacją. Podejmowane przez Moskwę próby satelizacji (wasalizacji) tych krajów bądź zablokowania ich prozachodniego kursu i ewentualne sukcesy na tym polu mają ponadto przełożenie na szerokie poparcie polityczne (ze strony części opozycji) dla kremlowskiej administracji, stanowiąc jeden z czynników - choć nie kluczowy legitymizacji rosyjskiej elity władzy. Obok aspiracji regionalnych Moskwa ujawniła na forum międzynarodowym swoje ambicje globalne. Pomimo strategicznego uwikłania na Ukrainie zaangażowała się w złożoną geopolityczną grę interesów na Bliskim Wschodzie, wspierając dyplomatycznie i militarnie swojego sojusznika, prezydenta Syrii Baszara al-Asada, w jego wojnie ze wspieraną przez Zachód, kraje arabskie i okresowo Turcję syryjską opozycją. Zdolność do punktowego powstrzymywania globalnych wpływów USA (obecnie podobną próbą jest polityka Kremla wobec Wenezueli) oraz znacząca zdolność koncyliacyjna (wchodzenie w sojusze z Chinami i Iranem) służą budowaniu w oczach rosyjskich władz i społeczeństwa wizerunku Rosji jako państwa silnego, zdolnego do obrony swoich interesów w świecie.

\section{Kreml a kolorowe rewolucje na obszarze postradzieckim}

Rosjanie pragną żyć godnie, a kremlowska propaganda z powodzeniem eksploatuje to, utożsamiając godność obywatela z godnością i prestiżem państwa na arenie międzynarodowej. Godność społeczeństwa czy narodu zależy więc

35 Zob. M. Kaczmarski, Rosyjski rewizjonizm wobec Zachodu, Ośrodek Studiów Wschodnich, Warszawa 2009 (Prace OSW, 33).

36 M. Stuermer, Putin..., s. 175. 
od godności państwa, ale oddziaływanie w drugą stronę nie jest już tak silne. Rosja Putina odzyskała kontakt ze społeczeństwem i zdolność jego mobilizacji, niwelując syndrom alienacji władzy charakterystyczny dla okresu jelcynowskiego. Państwo rosyjskie podejmowało próby eksportu wizerunku bogacącej się, silnej i dobrze prosperującej Rosji do innych krajów tzw. bliskiej zagranicy, co miało zwiększyć wśród ich społeczeństw atrakcyjność Kremla jako ośrodka efektywnie stabilizującego obszar postradziecki. Przekaz ten rozbijały jednak kolejne kolorowe rewolucje, których ostatnim przykładem była ukraińska rewolucja godności.

Na Kremlu nie podjęto konstruktywnej refleksji nad społecznymi źródłami tego rewolucyjnego fenomenu i nie rozpatrywano go w charakterze impulsu modernizacyjnego ${ }^{37}$. Potraktowany został instrumentalnie - jako inspiracja wspieranych z Zachodu organizacji pozarządowych, za którymi stoi kapitał amerykańskiego finansisty i spekulanta, orędownika liberalnej demokracji i idei społeczeństwa otwartego, George'a Sorosa ${ }^{38}$. Obecnie na Kremlu dominuje opinia, że kolorowe rewolucje były końmi trojańskimi - zewnętrznymi produktami polityczno-propagandowymi, które poprzez zachodnią agenturę implantowano na obszarze postradzieckim w celu pogłębiania jego dezintegracji, co przede wszystkim miało uderzyć w Rosję. Oficjalnie nie towarzyszy temu jednak głębsza refleksja, dlaczego akcje te porywały miliony ludzi i czy nie był to ich sprzeciw wobec stagnacyjnej elity konserwującej swoje przywileje i zabezpieczającej za pomocą potężnych środków administracyjnych (adminriesursu) mechanizmy, które wyniosły ją do władzy.

Za próbę wywołania kolorowej rewolucji w Rosji zostały uznane masowe antykremlowskie demonstracje na placu Błotnym w Moskwie, zwane ruchem białych wstążek. Były to największe antyrządowe manifestacje w tym kraju w XXI w. - trwały od grudnia 2011 do lutego 2012 r., gromadząc do 40 tys. ludzi protestujących przeciwko sfałszowaniu - jak twierdziła opozycja - wyborów parlamentarnych oraz ubieganiu się Władimira Putina o trzecią kadencję prezydencką (2012-2018). Kreml spacyfikował wystąpienia metodami administracyjnymi, represjonując przeciwników politycznych, reglamentując zezwolenia na manifestacje, a także mobilizując ponad 100 tys. swoich zwolenników w kontrdemonstracjach na Pokłonnej Górze w Moskwie.

Słabość antykremlowskiej opozycji jest istotnym czynnikiem warunkującym trwałość obecnego systemu władzy w Rosji. Komuniści, na których

37 W. Dubnow, Pomarańczowy kolor burżuazji, „Rosja w Globalnej Polityce”, maj 2005.

38 Zob. A. von Rétyi, George Soros..., s. 178-208. 
jeszcze w latach dziewięćdziesiątych XX w. Kreml był zmuszony bardzo uważać, nie stanowią dziś żadnej alternatywy dla putinizmu. Rosyjska opozycja sama z siebie nie jest żadną przeciwwagą dla obecnego reżimu, a gdy korzysta z pomocy i wsparcia z zagranicy, Kreml dyskredytuje ją w społeczeństwie jako obcą agenturę. Władze nierzadko sięgają wobec opozycjonistów po radykalne środki, jak bicie przez policję i siły porządkowe (zwłaszcza podczas manifestacji), ale też dotkliwe represje administracyjne - długie areszty czy wysokie kary finansowe. Opozycję, zwłaszcza tę o profilu liberalnym, Kreml traktuje często jako przeszkodę w urzeczywistnianiu wizji silnej i mocarstwowej Rosji, więc jej społeczna percepcja zazwyczaj jest negatywna.

We współczesnym świecie najefektywniejszą formą panowania jest władza nad ludzką świadomością, której jednak nie można zdobyć stalowymi pięściami armii pancernych, totalną wojną powietrzną czy nuklearną. Nie sprawdzi się też znane $\mathrm{z}$ epoki totalitarnej wpajanie określonej ideologii i systemu wartości z pomocą aparatu przymusu. Skuteczne konstruowanie politycznej dominacji wymaga stworzenia takiego systemu i jego wizerunku, który byłby propagowany w pozornie nieinwazyjnej formie i uznany przez społeczeństwo za własny. Kluczem do sukcesu jest utożsamienie się ludzi z systemem na zasadzie dobrowolności. Regułę tę - od dziesięcioleci z powodzeniem stosowaną np. w Stanach Zjednoczonych - zrozumiano także w Rosji, zwłaszcza po pomarańczowej rewolucji na Ukrainie. Kreowaniem wizerunku Kremla i jego skuteczną promocją (m.in. w przestrzeni WNP) miała się zająć nowa generacja rosyjskich technologów politycznych, wyedukowana na błędach popełnionych przez Rosję na Ukrainie ${ }^{39}$. Styl rosyjskich działań w porównaniu z zachodnimi (głównie amerykańskimi) mechanizmami reagowania w podobnych sytuacjach może się wydawać siermiężny, Kreml jednak pilnie studiuje zachodnie strategie komunikowania, powołując i wspierając liczne think tanki (czyli „fabryki myślenia”), projekty medialne i organizacje pozarządowe czy też tworząc i doskonaląc narzędzia i metody wojny hybrydowej. Rosyjscy stratedzy pojęli już, że warunkiem odgrywania znaczącej roli w polityce XXI w. jest stworzenie własnej sieci organizacji pozarządowych, instytutów doradczych, firm medialnych i instytucji gospodarczych oraz dostarczenie im ideologii, pieniędzy i $\mathrm{kadr}^{40}$. Budowa sieci zdominowanych

39 Zob. I. Krastev, Putinowskie „społeczeństwa obywatelskie”?, „Europa - Tygodnik Idei” 2005, $\mathrm{nr} 43$ (82).

40 Tamże. 
i nadzorowanych przez Moskwę podmiotów tego rodzaju stanowi fundament nowej polityki wobec obszaru postradzieckiego, traktowanego przez Rosję jako jej wyłączna geopolityczna strefa wpływów.

\section{Doktryny wewnętrzne - demokracja kierowana i demokracja suwerenna}

Jak już wspomniano, głównym czynnikiem determinującym poparcie społeczne dla Kremla była gospodarcza prosperity. $Z$ czasem jednak administracja Władimira Putina skoncentrowała wysiłki na próbach opracowania integralnej idei państwowo-narodowej (harmonijnie łączącej całość rosyjskiego doświadczenia historycznego i cywilizacyjnego), czym zajął się sztab kremlowskich intelektualistów.

$\mathrm{Na}$ gruncie wewnętrznym bardzo istotną kwestią jest zdefiniowanie rosyjskiego systemu w kategoriach demokratycznych. Zagraniczni i liberalni rosyjscy krytycy porządku politycznego wprowadzonego przez Putina (rzecznicy praw jednostki) skłonni są nazywać go systemem autorytarnym lub półautorytarnym. Politolodzy często mówią o demokracji kierowanej lub sterowanej (uprawlajemaja diemokratija), a sam Kreml utożsamia się z tym pojęciem jedynie w kontekście rządów prawa (w jego własnej interpretacji), jakkolwiek termin ten był również odnoszony przez politologów do systemu jelcynowskiego. Pojęcie demokracji kierowanej pojawiło się w Rosji pod koniec epoki Jelcyna, gdy kierowana przez Aleksandra Wołoszyna administracja prezydencka dążyła do odzyskania jak największej kontroli nad procesami politycznymi w kraju. Demokracja kierowana to system władzy, w którym formalnemu (technicznemu) przestrzeganiu procedur demokratycznych towarzyszy nacisk na wyborcę i narzucanie mu określonej decyzji. Skalę oddziaływania władzy państwowej potęguje brak świadomości obywatelskiej w rosyjskim społeczeństwie ${ }^{41}$. Demokracja kierowana opiera się na trzech głównych filarach: propagandzie, głównie telewizyjnej, gdzie projektowana rzeczywistość jawi się jako bardziej realna od prawdziwej; tajnych układach w najwyższych strukturach władzy; manipulacji systemem sądowniczym ${ }^{42}$. Demokrację sterowaną można także uznać za manipulowanie obywatelami

41 M. Fišman, Model' upravlâemoj demokratii $i$ vybory, „Demokratiâ” [online, dostęp: 15.07.2018], dostępny w internecie: <http://www.democracy.ru/library/practice/media/ media_in_regelect_2001/page 7.html $>$.

Tamże. 
przez władzę (głównie w procesie wyborczym) przy użyciu całego arsenału zasobów administracyjnych ${ }^{43}$.

Kremlowscy analitycy traktują takie interpretacje jako wykreowany przez politologów masowy stereotyp, który jednak wzmacniany jest faktem całkowitej dominacji Kremla w rosyjskiej polityce ${ }^{44}$. U podstaw wyraźnego politycznego prymatu prezydenta leży kilka czynników: postrzeganie jego rankingu poparcia jako wysokiego; brak alternatywnego lidera w obozie władzy; brak konkurencyjnej wobec Kremla masowej ideologizacji społeczeństwa; brak wpływowej niekomunistycznej opozycji; statyczny obraz stabilnej sytuacji w kraju rozpowszechniany w mediach (głównie telewizji); system masowych stereotypów (jak stabilizacja, powszechny szacunek wobec Rosji, demokracja kierowana); potężne środki administracyjne ${ }^{45}$. Elementem demokracji kierowanej jest także dyktatura prawa. Znajduje to wyraz w rozliczaniu się Kremla z oligarchią, gdzie stosowane są podwójne standardy - selektywne nakładanie sankcji. W opinii liberalnego rosyjskiego polityka Grigorija Jawlinskiego praktyki te są wyraźnym przejawem „kapitalizmu ze stalinowską twarzą”; Anatolij Czubajs - ekonomista z ekipy Jelcyna, który stworzył koncepcję Rosji jako liberalnego imperium - twierdzi natomiast, że działania najwyższych struktur władzy państwowej mają już wiele wspólnego z faszyzmem ${ }^{46}$.

$\mathrm{Na}$ Kremlu określanie rosyjskiego systemu mianem demokracji kierowanej odbierane jest sceptycznie, zwłaszcza w wydaniu zachodnich polityków i komentatorów, ponieważ postrzega się je jako werbalny wytrych służący ingerencji obcych państw w wewnętrzne sprawy Rosji i obszaru

43 J. Felsztinski, W. Pribyłowski, Korporacja..., s. 285-287.

44 Dawny doradca Władimira Putina Gleb Pawłowskij twierdził, że demokracja kierowana w ogóle nie jest ideologią. Zarządzanie demokracją uważał za zwykłe działanie władzy podejmowane np. na wypadek wyborów w celu ograniczenia ryzyka wybuchu niepokojów społecznych podsycanych podczas walki wyborczej. Miałoby to upodobnić Rosję do państw Zachodu, w których wybory nie powodują za każdym razem sytuacji rewolucyjnej. G. Pavlovskij, Politika ,upravlâemoj demokratii” ne pereživet vyborov prezidenta, a prezident Putin pereživet i èti vybory, i ètu politiku, „Kreml'” [online], 6.10.2002 [dostęp: 15.07.2018], dostępny w internecie: <http://www.kreml.org/opinions/4426034>.

45 Tamże.

46 P. de Sent-Èkzûperi, Diktatura zakona i upravlâemaâ demokratiâ Vladimira Putina, „Le Figaro”, [przedruk w:] „InoSMI” [online], 1.12.2003 [dostęp: 13.02.2008], dostępny w internecie: <https://inosmi.ru/inrussia/20031201/201032.html>. Na temat koncepcji dyktatu prawa w Rosji Putina w kontekście ,władzy prawa i władzy ponad prawem” zob. A. Ahiezer, I. Klâmkin, I. Âkovenko, Istoriâ Rossii. Konec ili novoe načalo?, Novoe izdatel'stvo, Moskva 2005, s. 648-667. Szerokiego wyjaśnienia kwestii demokracji kierowanej w kontekście dziejów Rosji po 1917 r. i z pozycji neomarksistowskich podjął się krytyczny wobec Kremla Borys Kagarlickij: B. Kagarlickij, Upravlâemaâ demokratiâ. Rossiâ, kotorû̂ nam navâzali, Ul'tra-Kul'tura, Ekaterinburg 2005. 
postradzieckiego $0^{47}$. Za demokracje kierowane uważa się tam reżimy niesamodzielne politycznie i gospodarczo, podczas gdy rosyjska demokracja przedstawiana jest jako w pełni suwerenna. Demokratyczna korekta procesów transformacyjnych na obszarze postradzieckim, która przyjęła formę kolorowych rewolucji (zwłaszcza pomarańczowa rewolucja), zmusiła jednak kremlowskich ideologów, strategów, filozofów i publicystów do opracowania bardziej spójnej koncepcji. Powstała w związku z tym idea demokracji suwerennej, sformułowana przez Nikitę Garadżę, Aleksieja Czadajewa, Witalija Trietiakowa, Maksima Sokołowa, Andrieja Kokoszyna i patronującego całemu projektowi Władisława Surkowa ${ }^{48}$. Ideolodzy Kremla odrzucili zarzut, że rosyjska władza z prezydentem Putinem na czele kieruje się wyłącznie celami korporacyjnymi, podkreślając, że wystarczająco rozróżnia ona interesy korporacji i państwa, które wymaga znacznie szerszej odpowiedzialności wobec historii i społeczeństwa. Warto jednak zwrócić uwagę, że odpowiedzialność za państwo i za korporację może być dialektycznie (w ramach występujących między nimi sprzeczności) i pragmatycznie (w celu maksymalizacji korzyści politycznych) pogodzona, co władza na Kremlu i jej ideolodzy zapewne rozumieją. W jelcynowskiej półliberalnej wersji demokracji kierowanej władza nie stosowała nacisków na społeczeństwo, tylko je ignorowała. Demokracja kierowana była wówczas ustrojem, który uwalniał elity od konieczności rządzenia, dając im czas na zajęcie się własnymi interesami ${ }^{49}$.

Suwerenność w rozumieniu putinowskim to potencjał państwa, jego niezależność ekonomiczna, potęga wojskowa i tożsamość kulturowa. Ważnym elementem jest też elita o poglądach narodowych, a jej kształtowanie to podstawowe zadanie demokracji suwerennej jako projektu ${ }^{50}$. Z perspektywy zachodniego rozumienia demokracji putinowski suwerenizm cechują jednak pewne defekty: nacjonalizacja elity przyczyniła się do nacjonalizacji sektora energetycznego, przejęcia całkowitej kontroli nad mediami, sterowania przez Kreml partiami politycznymi, represyjnego prześladowania przeciwników politycznych, a także ustanowienia struktur, które aktywnie wspierałyby reżim w wypadku kryzysu (konsolidacja adminriesursu). Suwerenność

47 Zob. A. Matveeva, V Rossii net upravlâemoj demokratii. Vladimir Putin ne znaet, čto èto takoe, „Gorodskie zametki” [online, dostęp: 5.02.2008], dostępny w internecie: <http:// www.gzt.ru/politics/2005/09/06/205857.html>; Vladislav Surkov razvel demokratiû na suverennuй i upravlâemuû, „Kommersant"”' [online], 29.06.2006 [dostęp: 15.07.2018], dostępny w internecie: <http://www.kommersant.ru/doc.aspx?docsID=686274>.

Zob. Suverenitet, red. N. Garadža, Evropa, Moskva 2006; A. Čadaev, Putin. Ego ideologiâ, Evropa, Moskva 2006.

49 I. Krastev, Suwerenna demokracja...

50 Tamże. 
władzy wyraźnie dominuje w tym systemie nad suwerennością obywateli, do których Kreml tradycyjnie nie ma zaufania. Projekt demokracji suwerennej stanowi wobec tego negację i odrzucenie anglosaskiego modelu demokracji liberalnej, legitymizowanej przez prawa człowieka i zasadę wzajemnej kontroli organów władzy; jest osobliwą narodową teorią demokratyczną i z pewnością czymś więcej niż tylko konstrukcją propagandową ${ }^{51}$. Raczej ignorowana przez Zachód koncepcja demokracji suwerennej nie zakłada wcale zerwania $z$ europejską tradycją; jest jakby wyrazem dążenia przez Rosję do stania się inną Europą - alternatywą dla Unii Europejskiej ${ }^{52}$. Europejskie społeczeństwa, funkcjonując pod presją globalizacji i wzbierającej fali populizmu, mogą się rozczarować magią postmodernistycznego państwa $\mathrm{w}$ formie Unii Europejskiej i mimowolnie ulec dyskretnemu urokowi demokracji suwerennej, co być może następuje już obecnie.

Demokrację suwerenną można też rozpatrywać jako kolejną po euroazjatyzmie ideę naczelną w dziejach Rosji próbującą godzić wewnętrzne sprzeczności (antynomie) - zjawisko właściwe dla reżimów powstałych w sferze kultury prawosławia ${ }^{53}$. W refleksji nad rosyjskim systemem kluczowy jest fakt, że demokracja jako określony zespół reguł i procedur stanowi ważną metodę legitymizacji reżimu, nowocześniejszą niż skompromitowany w poprzedniej epoce komunistyczny totalitaryzm, który pozbawiony był pragmatycznej elastyczności ideologicznej. Zawsze będzie ona ładną dekoracją, przynajmniej formalnie dającą rosyjskiej władzy mandat społeczny. Można się zatem spodziewać, że kremlowska elita uczyni wiele, by zachować w Rosji demokratyczne procedury. W epoce Jelcyna nie wypracowano żadnej ideologii, a tylko technologię władzy, natomiast próby jej konsolidacji oznaczały nieustanną grę w kolejne polityczne intrygi i ,niezawodne systemy" ${ }^{54}$. Reżim Putina cechuje się natomiast ideowym synkretyzmem i może być definiowany jako „umiarkowany i oświecony autorytaryzm z elementami kontrolowanej demokracji”,55.

\section{Polityka historyczna}

Istotnym czynnikiem warunkującym trwałość obecnego sytemu władzy w Rosji jest polityka historyczna. Administracja Władimira Putina, reorganizując państwo, korzystała z całego doświadczenia dziejowego Rosji:

51 Tamże.

52 Tamże.

53 J. Staniszkis, Antropologia..., s. 127.

54 W. Marciniak, Kryzys społeczeństwa postsowieckiego, „Res Publica Nowa” 1998, nr 11, s. 45.

55 Rosja. XX wiek..., s. 170. 
przedrewolucyjnego, radzieckiego i postradzieckiego. Można to nazwać synkretycznym postmodernizmem w wydaniu władzy państwowej, obliczonym na wykreowanie szerokiego konsensusu społecznego w kwestii dziedzictwa historycznego. Strategiczną linią pierwszych dziesięcioleci XXI w. najprawdopodobniej stanie się integracja tradycjonalistycznych rosyjsko-radzieckich orientacji ${ }^{56}$. Obecnie znajduje to swoje potwierdzenie w kultywowaniu przez władze rosyjskie kluczowych heroicznych momentów i wydarzeń w historii Rusi Kijowskiej, Imperium Rosyjskiego i Związku Radzieckiego, kreowaniu ciągłości historycznej między tymi kształtowanymi przecież na wzajemnej negacji kolejnymi formacjami państwowymi oraz transmitowaniu do społeczeństwa obrazu współczesnej Rosji jako ich dziejowej syntezy.

Postradziecka Rosja Borysa Jelcyna, mając w pamięci smutne i straszne doświadczenia ZSRR, przejawiała wielką awersję wobec wszelkich ideologii. W symbolice państwowej nawiązano do czasów przedrewolucyjnych, a wszelkie inwokacje do radzieckiej świetności odbierane były w obozie prezydenta negatywnie. On sam zresztą, jeśli już musiał szukać uzasadnień ideologicznych, starał się odwoływać do demokracji liberalnej, ale wobec braku silnych rodzimych tradycji demokratycznych nie było to dla Rosjan przekonujące. Władimir Putin natomiast dostrzegał, że większość społeczeństwa jest bezideowa i skupiona głównie na statusie materialnym; rozumiał, że wielu obywateli nie akceptuje nowej formy rosyjskiej państwowości i jej symboliki, a starsze pokolenie odczuwa nostalgię za imperium ${ }^{57}$. Skutki bezideowości i braku wychowania patriotycznego w epoce Jelcyna uwidoczniło niskie morale armii walczącej na Kaukazie podczas pierwszej wojny czeczeńskiej. Po latach ideologicznej smuty zaczęły więc dojrzewać na Kremlu projekty ideowej reanimacji społeczeństwa i oficjalnej państwowej polityki historycznej, kreujące rosyjski patriotyzm narodowy, a najlepiej federacyjny (quasi-imperialny).

56 Zob. tamże, s. 170.

57 Według badań socjologicznych z 1998 r. z postradziecką Rosją utożsamiał się niewielki odsetek rosyjskiego społeczeństwa: zaledwie $12 \%$ obywateli uznawało władzę państwową Federacji Rosyjskiej za legalną, 2\% za narodową i 3\% za swoją. Silna natomiast pozostawała identyfikacja z ZSRR, dla którego wskaźniki te wynosiły odpowiednio: 32\%, 36\% i 32\%. A. Salmin, Legal'nost', legitimnost' i pravopreemstvo kak problemy segodnâšnej rossijskoj gosudarstvennosti, „Politiâ” 1998, nr 1, s. 62. Bezpośrednio po rozpadzie ZSRR nostalgię za imperium wyrażało jedynie 16-20\% Rosjan. I. Klâmkin, Političeskaâ sociologiâ perehodnogo perioda, „Polis” 1993, nr 4, s. 57. Z największym entuzjazmem idea restytucji ZSRR spotykała się w tym czasie (1992) wśród kadry oficerskiej wojska. Jak wykazał powołujący się na rosyjskich badaczy Włodzimierz Marciniak, popierało ją 71\% oficerów armii rosyjskiej. W. Marciniak, Rozgrabione imperium. Upadek Związu Sowieckiego i powstanie Federacji Rosyjskiej, Wydawnictwo Arcana, Kraków 2004, s. 197. 
Administracja Putina postanowiła definitywnie skończyć z ideologicznymi zaniechaniami i przebudzić społeczeństwo z ideowego letargu - zainteresować je losami państwa i związać z nim poprzez nową formułę rosyjskiego patriotyzmu oraz obudzenie poczucia dumy narodowej i państwowej. Wykorzystano do tego drugą wojnę czeczeńską i akty heroizmu rosyjskich żołnierzy w walce z międzynarodowym terroryzmem, które eksponowano w kulturze masowej, zwłaszcza kinematografii. Wyciągnięto też z lamusa heroizm radziecki i całą mitologię zwycięstwa nad faszyzmem w czasie tzw. wielkiej wojny ojczyźnianej, co miało integrować przestrzeń postradziecką na płaszczyźnie pamięci historycznej ${ }^{58}$. Kreml odszedł jednak od kultywowania etosu bolszewickiego, z którego atrakcyjny mógł być dla niego warunkowo wątek Czeka. Kolejnym etapem kreowania postaw patriotycznych było ustanawianie nowych świąt państwowych odwołujących się do wydarzeń historycznych, np. upamiętniającego wyparcie wojsk polskich z Moskwy w 1612 r. Dnia Jedności Narodowej (4 listopada), który zastąpił obchodzone 7 listopada święto rewolucji bolszewickiej.

W projekcie rosyjskiego przebudzenia narodowego nie chodziło bynajmniej o prawdę historyczną. Z perspektywy Kremla sytuacja, w której przeciętny obywatel podejmowałby się rozstrzygania o prawdzie w historii, byłaby bardzo niepożądana; powinien on raczej zdecydowanie i bezkrytycznie akceptować i celebrować nową tradycję. Wskazane wyżej działania władzy państwowej są projektem pragmatycznym, w którym idea czy ideologia nie jest źródłem przekonań, ale instrumentem ich stymulacji - budzenia lub też kreowania tożsamości i dumy narodowej, emocjonalnej więzi z państwem i narodem oraz jego wspaniałą bohaterską przeszłością. W postradzieckiej Rosji rywalizują ze sobą cztery zasadnicze koncepcje historii i historiografii: słowianofilska, okcydentalistyczna, państwowa (zmieniająca się zależnie od koniunktury politycznej) oraz faktograficzna (oparta na dokumentach i badaniach archeologicznych, ale dostępna jedynie wąskiemu gronu specjalistów) ${ }^{59}$.

W okresie interwału miedwiediewowskiego lub tandemokracji, tzn. zamieniającej sięnajwyższymi urzędami państwowymi konstelacji Putin-Miedwiediew

58 Zob. W. Materski, Od cara do „cara”. Studium rosyjskiej polityki historycznej, Instytut Studiów Politycznych PAN, Warszawa 2017, s. 266-276. Monografia prof. Wojciecha Materskiego stanowi interesujące, kompleksowe opracowanie polityki historycznej Rosji dotyczące całej historii tego kraju.

59 Zob. rozmowę z prof. prof. Jurijem Borysionkiem i Wadimem Erlichmanem: Niepewne wczoraj. Dlaczego w Rosji byto lepiej, kiedy było gorzej, „Ogonëk”, 11.12.2006, [przedruk w:] „Forum” 2007, nr 39. Zob. też J. Sobczak, Nowe tendencje wspótczesnej historiografii rosyjskiej, [w:] Powrót do historii. Europa Środkowa i Wschodnia w historiografii, red. W. Balcerak, Instytut Historii PAN, Warszawa 1994, s. 47-68. 
(2008-2012), można było zaobserwować istotny trend modernizacyjny w polityce gospodarczej i ideologicznej. Prezydentura Dmitrija Miedwiediewa, który popadał niekiedy w drobne konflikty z Władimirem Putinem, miała być okresem koncentracji na gospodarce i rozwoju nowych technologii. Miedwiediew zakładał, że technologiczna modernizacja Rosji nie jest możliwa bez zmiany mentalności, bez rozprawy z pewnymi mitami i wyobrażeniami historycznymi, które kultywowało rosyjskie społeczeństwo. Stał się on zatem rzecznikiem destalinizacji świadomości, uważając (ponownie już jako premier), że rola Józefa Stalina w historii Rosji była zdecydowanie bardziej negatywna niż pozytywna, gdyż unicestwiając miliony Rosjan, zniszczył on świadomość obywatelską tego narodu, a zatem podwaliny społeczeństwa obywatelskiego ${ }^{60}$.

Krytyka komunizmu pobrzmiewa także w wypowiedziach prezydenta Putina, który postawę bolszewików podczas pierwszej wojny światowej nazwał zdradą narodową ${ }^{61}$. Ten enuncjacyjny i selektywny antykomunizm Kremla może być rozpatrywany zarówno jako próba zmierzenia się ze złożoną historią Rosji w XX w., jak i instrument dezawuowania mitów założycielskich komunistycznej opozycji poprzez ukazywanie jej niepatriotycznego czy nawet antypatriotycznego rodowodu. Retoryczna destalinizacja w wydaniu premiera Miedwiediewa może być przy tym koniecznym warunkiem technologicznej modernizacji kraju, ponieważ społeczna nostalgia za stalowo-węglowym imperium Stalina (widoczna zwłaszcza wśród starszego pokolenia Rosjan, którym trudniej zaadaptować się do dynamicznych zmian zachodzących w świecie) sabotuje wizję nowoczesnej Rosji. Jednak dewaluacji przy tym ulega wymiar aksjologiczny (etyczno-moralny), który powinien być punktem wyjścia dla oceny całej epoki stalinowskiej. Jest to o tyle istotne, że zdaniem znacznej części Rosjan czasy te miały swoje niezaprzeczalne osiągnięcia, Stalin przekształcił bowiem ZSRR w industrialne i atomowe supermocarstwo, które przez niemal pół wieku poważnie wpływało na losy świata. Wielu Rosjan zna też jednak straszną cenę tych sukcesów.

$60 \quad 30.10 .2012$ r. w Permie, na spotkaniu z działaczami prokremlowskiej partii Jedna Rosja z okazji Dnia Pamięci Ofiar Represji Politycznych, Miedwiediew stwierdził, że Stalin prowadził wojnę z własnym narodem, co jest najcięższą zbrodnią. Zob. T. Szeląg, Miedwiediew krytykuje Stalina. ,, Wojna ze swoim narodem to najcięższa zbrodnia”, „Onet” [online], 12.11.2012 [dostęp: 27.11.2012], dostępny w internecie: <https://wiadomosci.onet.pl/swiat/ miedwiediew-krytykuje-stalina-wojna-ze-swoim-narodem-to-najciezsza-zbrodnia/lyet5>.

61 Putin wyraził tę kategoryczną opinię 27.06.2012 r., podczas wizyty w Radzie Federacji. Zob. Putin oskarżyt bolszewików o zdradę narodowa, „Onet” [online], 28.06.2012 [dostęp: 15.07.2018], dostępny w internecie: <http://wiadomosci.onet.pl/swiat/putin-oskarzyl-bolszewikow-o-zdrade-narodowa,1,5173716, wiadomosc.html>. 
Polityka historyczna Rosji Putina jest jednym z elementów konsolidacji strefy wpływów na obszarze postradzieckim poprzez mobilizację przyjaznych mu grup społecznych za granicą. Najbardziej wyraziście przejawia się to w sformułowanej na początku XXI w. koncepcji russkiego miru (ruskiego ludu/narodu, ruskiego świata). Można uznać, że pojęcie to oznacza wspólnotę narodowo-kulturową i historyczno-polityczną ludności rosyjskojęzycznej zamieszkującej obszar byłego ZSRR oraz inne rejony świata ${ }^{62}$. Apelując do ruskiego uniwersum cywilizacyjnego, podkreśla się jedność językową, bliskość tradycji kulturowej, a także rangę prawosławia jako źródła i fundamentu kultury ruskiej. Eksponowane są przede wszystkim wspólne dzieje, mity i symbole, jak Ruś Kijowska i wielka wojna ojczyźniana. Istotnym elementem tego projektu jest przywrócenie pamięci historycznej, zwłaszcza wśród rosyjskiej diaspory na Zachodzie, do której adresowane są kult imperium Romanowów i rehabilitacja rosyjskiej emigracji porewolucyjnej. W ramach koncepcji russkiego miru wskazuje się również na pozytywne osiągnięcia epoki radzieckiej. Jej ważnym składnikiem jest prezentacja Federacji Rosyjskiej jako państwa przyjaznego, nowoczesnego, rozwiniętego gospodarczo i gotowego do obrony interesów rodaków (sootieczestwienników). Wszystko to ma wzmacniać poczucie jedności i solidarności „ruskich ludzi” oraz inspirować ich dążenie do integracji politycznej i kulturowej z Rosją jako ojczyzną. Koncepcja russkiego miru eksploatowana jest przez propagandę państwową, stanowiąc część rosyjskiego arsenału soft power. W tym kontekście uzasadnione jest postrzeganie działań Rosji wobec Ukrainy i Białorusi jako jej polityki wewnętrznej.

\section{Refleksje końcowe}

Putinowska transformacja Rosji wpisuje się w typowy dla tego obszaru model konserwatywnej modernizacji, jednak opartej już o reguły rynkowe ${ }^{63}$. Organy państwa zostały przekształcone w biurokratyczną sieć kooperacyjną, w której obowiązują dawne zasady patronatu nomenklatury, a nad sprawnością całego mechanizmu czuwa wszechwładna korporacja - FSB. System władzy politycznej w Rosji zasadniczo nie opiera się na żadnej kompletnej i spójnej ideologii, choć jej najwyższe organy zdołały w pewnym stopniu wypełnić pokomunistyczną próżnię ideologiczną - często starymi treściami aplikowanymi

62 Zob. A. Wierzbicki, Russkij mir jako projekt restauracyjny imperium, [w:] Rosja. Rozważania imperiologiczne, red. S. Bieleń, A. Skrzypek, Oficyna Wydawnicza ASPRA-JR, Warszawa 2015, s. 101-136.

63 Rosja. XX wiek..., s. 170. 
w nowej, niedogmatycznej formie, subiektywnie integrującymi różne aspekty i tradycje rosyjskiego doświadczenia cywilizacyjnego i historycznego. Rosja wciąż poszukuje optymalnej idei państwowej i narodowej, ale już sam ten proces wydaje się istotniejszy niż cel, do którego zmierza, ponieważ pozwala utrzymać stan społecznej i intelektualnej mobilizacji, którą można dowolnie kanalizować. W obecnej epoce ekonomicystycznego pragmatyzmu, racjonalizmu i postmodernistycznej dezideologizacji pojęć działalność polityczna tylko w nikłym zakresie podporządkowana bywa ideom czy ideologiom; pełnią one najczęściej i co najwyżej funkcję partyjnego logo.

Zasadniczym celem każdej działalności politycznej - nie tylko w Rosji jest zdobycie i utrzymanie władzy. Do jej sprawowania pożądane są szeroka legitymizacja społeczna wyrażona w ramach demokratycznych procedur oraz reguły gry politycznej (pojęcie demokracji jest przy tym bardzo pojemne). Realizacja programu, dzięki któremu poszczególne formacje polityczne zdobywają władzę, stanowi w tej pragmatycznej logice element drugoplanowy. Systemy demokratyczne (szczególnie w państwach postkomunistycznych) wymagają częstych korekt w postaci reform, których przeprowadzenie może się wiązać $\mathrm{z}$ wysokimi kosztami politycznymi i utratą poparcia społecznego. Wyraźnie dominujące w życiu politycznym danego kraju grupy sprawujące władzę dążą więc najczęściej do stworzenia mechanizmów zabezpieczających ich wpływy polityczne na wypadek wysokiej ceny realizacji programu czy reform. W Rosji taką dominującą pozycję zdobył za czasów Jelcyna obóz prezydencki i w końcowym okresie jego urzędowania postawił sobie za główny cel powstrzymanie dalszej dezintegracji kraju.

Obecnie raczej trudno oczekiwać w Rosji sytuacji rewolucyjnej na miarę 1917 albo 1991 r. Większość społeczeństwa zmęczona jest brakiem stabilizacji w epoce jelcynowskiej i z pewnością nie życzyłaby sobie takiego scenariusza; wyjątek może stanowić część kawiarnianej, głównie liberalnej, inteligencji tudzież lewicowi i prawicowi radykałowie. Aktualnie Rosjanie zaabsorbowani są konsumpcją stabilizacji i bynajmniej nie pragną gruntownych zmian. Rosyjska władza zdołała przekonać społeczeństwo, że za spokój wewnętrzny i ekonomiczną stabilizację warto zapłacić etatystyczną korektą demokracji wyposażającą administrację prezydenta w narzędzia powszechnej kontroli, a zatem de facto ograniczeniem systemu demokratycznego.

W rozważaniach na temat władzy i społeczeństwa można spotkać pogląd, że nie istnieje władza nieakceptowana społecznie, odnoszony także do systemów totalitarnych (wyjątkiem są jedynie reżimy okupacyjne). Nawet jeśli reżim egzekwuje swoją władzę za pomocą strachu, przymusu czy terroru, to 
z czasem uzyskuje większą liczbę zwolenników niż przeciwników, abstrahując od etyczno-moralnej jakości takiej legitymizacji. Obecne rządy w Rosji trudno nazwać totalitarnymi, chociaż można przyjąć, że mają posttotalitarne korzenie i nawyki. Ich immamentnymi cechami są korporacjonizm (ład korporacyjny) i zdolność skutecznego rozgrywania nastrojów społecznych w celu realizacji własnych celów, w czym pomaga wyspecjalizowany aparat socjotechniczny. W tej sytuacji konwencjonalnie pojmowane idee czy ideologie społeczno-polityczno-gospodarcze tracą rację bytu jako podstawa praktyki politycznej, stając się częścią werbalnego rytuału władzy oraz tradycji, do której w razie potrzeby można się odwołać w ramach przyjętych strategii retorycznych. W optyce rosyjskiej elity władzy wartością nadrzędną lub też ideą przewodnią jest $\mathrm{w}$ tym kontekście demokracja proceduralna (techniczna), będąca też użytecznym instrumentem kreowania rzeczywistości społeczno-politycznej. W połączeniu $\mathrm{z}$ faktycznym relatywizmem ideologicznym ma ona odpowiadać wymogom epoki i realizować interesy rządzących.

Problem trwałości obecnego systemu władzy w Federacji Rosyjskiej (roboczo nazywanego tu systemem putinowskim lub putinizmem) to zagadnienie złożone, obejmujące wiele komponentów. Zrozumienie mechanizmów konsolidacji systemu władzy w Rosji wymaga przedstawienia jego genezy. Źródeł jego legitymizacji należy też poszukiwać w uwarunkowaniach ekonomicznych i geopolitycznych oraz specyfice rosyjskiej kultury politycznej, którą cechują silna personalizacja władzy i słabość opozycji - często wskazywanej jako ukryty wróg. W celu silniejszego zintegrowania państwa $\mathrm{z}$ obywatelami podjęto na Kremlu próbę wykreowania oficjalnej ideologii państwowej doktryny demokracji suwerennej, a następnie ideowego przeciwstawienia jej rezultatom kolorowych rewolucji na obszarze postradzieckim. Silną i stabilną pozycję Władimira Putina determinują także polityka zagraniczna oraz wzrost roli i znaczenia Rosji na arenie międzynarodowej w ostatnim dwudziestoleciu. Ranking rosyjskiego prezydenta wzmacniają również dokonania putinowskiej administracji w przezwyciężaniu postradzieckiego kryzysu gospodarczego lat dziewięćdziesiątych XX w., i to mimo obecnego pogorszenia się sytuacji ekonomicznej kraju w wyniku sankcji międzynarodowych. Budowaniu masowego poparcia społecznego dla obecnej władzy służy także określona polityka historyczna, syntetyzująca całe rosyjskie dziedzictwo historyczno-kulturowe i kształtująca tożsamość Rosjan w oparciu o dominującą w oficjalnym przekazie heroiczną wizję dziejów narodu. Istotnym czynnikiem trwałości systemu putinowskiego jest osobliwa zdolność rosyjskiego społeczeństwa do ponoszenia nawet znacznych kosztów ekonomicznych, 
jeżeli są one konsekwencją działań podejmowanych przez rząd w celu realizacji definiowanych przez władzę interesów państwa na arenie międzynarodowej. Konserwatywni z natury Rosjanie słabo tolerują natomiast radykalne reformy ustrojowe, a rosyjska władza przejawia tendencje do notorycznego generowania głębokich kryzysów strukturalnych, szczególnie gdy zawodzą realizowane formuły modernizacyjne (cała historia Rosji to permanentne stadium „doganiającej modernizacji”). Następuje wówczas implozja systemu, dochodzi do wybuchów społecznych i pojawia się sytuacja rewolucyjna. Brak efektywnych strategii modernizacyjnych lub też niezdolność do ich płynnej i zrównoważonej implementacji może zatem stać się przyczyną zakwestionowania systemu i katalizatorem zmian.

\section{Bibliografia}

Ahiezer A., Klâmkin I., Âkovenko I., Istoriâ Rossii. Konec ili novoe načalo?, Novoe izdatel'stvo, Moskva 2005.

Biełkowski S., Biznes Władimira Putina. Zakończenie, [w:] Imperium Putina, red. W. Konończuk, Fundacja im. Stefana Batorego, Warszawa 2007.

Bryc A., Rosja w XXI wieku. Gracz światowy czy koniec gry?, Wydawnictwa Akademickie i Profesjonalne, Warszawa 2008.

Bunič A., Osen' oligarhov. Istoriâ prihvatizacii i buduŝee Rossii, Èksmo, Moskva 2005.

Čadaev A., Putin. Ego ideologiâ, Evropa, Moskva 2006.

Dubnow W., Pomarańczowy kolor burżuazji, „Rosja w Globalnej Polityce”, maj 2005.

Felsztinski J., Pribyłowski W., Korporacja zabójców. Rosja, KGB i prezydent Putin, przeł. C. Murawski, posł. opatrzył W. Marciniak, Prószyński i S-ka, Warszawa 2008.

Fišman M., Model' upravlâemoj demokratii i vybory, „Demokratiâ” [online, dostęp: 15.07.2018], dostępny w internecie: $<$ http://www.democracy.ru/library/practice/media/media_in_regelect_2001/page7.html>.

Fiszer J., Włodzimierz Putin - dlaczego zaufała mu cała Rosja? Specyficzne formy przywództwa politycznego, [w:] Przywództwo i elity polityczne w krajach WNP, red. T. Bodio, W. Jakubowski, Oficyna Wydawnicza ASPRA-JR, Warszawa 2010.

Furier A., Dekada Jelcyna. Uwarunkowania rosyjskich przemian społecznych i politycznych 1991-2000, Wydawnictwo Naukowe US, Szczecin 2003.

Grajewski A., Tarcza i miecz. Rosyjskie stużby specjalne 1991-1998, Biblioteka „Więzi”, Warszawa 1998.

Imperium Putina, red. W. Konończuk, Fundacja im. Stefana Batorego, Warszawa 2007.

Kaczmarski M., Rosyjski rewizjonizm wobec Zachodu, Ośrodek Studiów Wschodnich, Warszawa 2009 (Prace OSW, 33).

Kagarlickij B., Upravlâemaâ demokratiâ. Rossiâ, kotorû̂ nam navâzali, Ul'tra-Kul'tura, Ekaterinburg 2005.

Klâmkin I., Političeskâ̂ sociologiâ perehodnogo perioda, „Polis” 1993, nr 4.

Koncepciâ vnešnej politiki Rossijskoj Federacii, „Diplomatičeskij vestnik” 2000, № 8.

Krastev I., Putinowskie „, społeczeństwa obywatelskie”?, „Europa-Tygodnik Idei” 2005, nr 43 (82). 
Krastev I., Suwerenna demokracja. Nowa rosyjska ideologia, „Europa”, [dodatek do:] „Newsweek Polska”, 26.08.2007.

Krastev I., Suwerenna demokracja. Nowa rosyjska ideologia, „Europa - Tygodnik Idei”, [dodatek do:] „Dziennik”, 26.08.2007.

Kryštanovskaâ O., Anatomiâ rossijskoj èlity, Zaharov, Moskva 2004.

Liparteliani G., Prawda o Putinie. Polityczny kardiogram Rosji, przeł. M. Kotowska, Oficyna Wydawnicza Rytm, Warszawa 2001.

Litwinienko A., Felsztinski J., Wysadzić Rosję, przeł. M. Szymański, Dom Wydawniczy Rebis, Poznań 2007.

Marciniak W., Kryzys społeczeństwa postsowieckiego, „Res Publica Nowa” 1998, nr 11.

Marciniak W., Rozgrabione imperium. Upadek Zwiazku Sowieckiego i powstanie Federacji Rosyjskiej, Wydawnictwo Arcana, Kraków 2004.

Materski W., Od cara do „cara”. Studium rosyjskiej polityki historycznej, Instytut Studiów Politycznych PAN, Warszawa 2017.

Matveeva A., V Rossii net upravlâemoj demokratii. Vladimir Putin ne znaet, čto èto takoe, „Gorodskie zametki” [online, dostęp: 5.02.2008], dostępny w internecie: $<$ http://www.gzt. ru/politics/2005/09/06/205857.html>.

Mazo B., Piterskie protiv moskovskih, ili kto est' kto v okruženii V.V. Putina, Èksmo-Algoritm, Moskva 2003.

Medvedev R., Vladimir Putin: Četyre goda v Kremle, Vremâ, Moskva 2004.

Miecik I., Gwardia Putina, „Polityka”, 20.08.2005.

Miedwiediew R., Władza i biznes w nowej Rosji, „Dziś. Przegląd Społeczny” 2004, nr 1.

Muhin A., Putin. Bližnij krug prezidenta, Algoritm, Moskva 2005.

Niepewne wczoraj. Dlaczego w Rosji byto lepiej, kiedy było gorzej, „Ogonëk”, 11.12.2006, [przedruk w:] „Forum” 2007, nr 39.

Pavlovskij G., Politika „upravlâemoj demokratii” ne pereživet vyborov prezidenta, a prezident Putin pereživet i èti vybory, i ètu politiku, „Kreml"” [online], 6.10.2002 [dostęp: 15.07.2018], dostępny w internecie: <http:/www.kreml.org/opinions/4426034>.

Powrót do historii. Europa Środkowa i Wschodnia w historiografii, red. W. Balcerak, Instytut Historii PAN, Warszawa 1994.

Przywództwo i elity polityczne $w$ krajach WNP, red. T. Bodio, W. Jakubowski, Oficyna Wydawnicza ASPRA-JR, Warszawa 2010.

Putin oskarżyt bolszewików o zdradę narodowa, „Onet” [online], 28.06.2012 [dostęp: 15.07.2018], dostępny w internecie: <http://wiadomosci.onet.pl/swiat/putin-oskarzyl-bolszewikow-o-zdrade-narodowa,1,5173716, wiadomosc.html>.

Radziwinowicz W., Wyuczony czekista, „Gazeta Wyborcza”, 29.12.2009.

Reitschuster B., Władimir Putin. Dokad prowadzi Rosję?, przeł. M. Zeller, Bertelsmann Media, Warszawa 2005.

Rétyi A., George Soros. Multimiliarder, jego globalna sieć i koniec takiego świata, jaki znamy, przeł. E. Lubelska, Biały Kruk, Kraków 2016.

Rosja. XX wiek. Od utopii komunistycznej do rzeczywistości globalistycznej, red. J. Zołotowskij, przeł. P. Burek, Wydawnictwo Uniwersytetu Jagiellońskiego, Kraków 2004.

Rosja. Rozważania imperiologiczne, red. S. Bieleń, A. Skrzypek, Oficyna Wydawnicza ASPRA-JR, Warszawa 2015.

Salmin A., Legal'nost', legitimnost' i pravopreemstvo kak problemy segodnâšnej rossijskoj gosudarstvennosti, „Politiâ” 1998, nr 1. 
Sent-Èkzûperi P. de, Diktatura zakona i upravlâemaâ demokratiâ Vladimira Putina, „Le Figaro”, [przedruk w:] „InoSMI” [online], 1.12.2003 [dostęp: 13.02.2008], dostępny w internecie: $<$ https://inosmi.ru/inrussia/20031201/201032.html>.

Skrzypek A., Druga smuta. Zarys dziejów Rosji 1985-2004, Oficyna Wydawnicza ASPRA-JR, Warszawa 2004.

Sobczak J., Nowe tendencje współczesnej historiografii rosyjskiej, [w:] Powrót do historii. Europa Środkowa $i$ Wschodnia w historiografii, red. W. Balcerak, Instytut Historii PAN, Warszawa 1994.

Sogrin V., Političeskaâ istoriâ sovremennoj Rossii. 1985-2001. Ot Gorbačeva do Putina, Ifra-M - Ves' mir, Moskva 2001.

Staniszkis J., Antropologia władzy. Między Traktatem Lizbońskim a kryzysem, Prószyński i S-ka, Warszawa 2009.

Staniszkis J., Postkomunistyczne państwo: w poszukiwaniu tożsamości, Instytut Spraw Publicznych, Warszawa 2000.

Staniszkis J., Postkomunizm. Próba opisu, Słowo/Obraz Terytoria, Gdańsk 2001.

Staniszkis J., Marciniak W., Świder K., Sekularyzacja myślenia politycznego w Rosji. Przejście od religijnej idei ,właściwego istnienia” do koncepcji imperium i geopolityki, Instytut Studiów Politycznych PAN, Warszawa 2016.

Stuermer M., Putin i odrodzenie Rosji, przeł. B. Madejski, Wydawnictwo Dolnośląskie, Wrocław 2010.

Suverenitet, red. N. Garadža, Evropa, Moskva 2006.

Szeląg T., Miedwiediew krytykuje Stalina. „,Wojna ze swoim narodem to najcięższa zbrodnia”, „Onet” [online], 12.11.2012 [dostęp: 27.11.2012], dostępny w internecie: <https:// wiadomosci.onet.pl/swiat/miedwiediew-krytykuje-stalina-wojna-ze-swoim-narodem-to-najciezsza-zbrodnia/lyet5>.

Świder K., Ewolucja elity władzy w Zwiąku Radzieckim i Rosji w kontekście przemian ideowych, politycznych, społecznych i ekonomicznych, Instytut Studiów Politycznych PAN, Warszawa 2013.

Świder K., Geopolityka jako „,światopoglad władzy w Rosji”, „Studia Polityczne” 2017, nr 1.

Świder K., Osobliwości metodologiczne rosyjskiej geopolityki, „Myśl Ekonomiczna i Polityczna" 2016, nr 4.

Vladislav Surkov razvel demokratiû na suverennuи̂ i upravlâemuû, „Kommersant"” [online], 29.06.2006 [dostęp: 15.07.2018], dostępny w internecie: <http://www.kommersant.ru/ doc.aspx?docsID $=686274>$.

Walicki A., Odpowiedź Michnikowi, „Gazeta Wyborcza”, 12-13.01.2008.

Wierzbicki A., Russkij mir jako projekt restauracyjny imperium, [w:] Rosja. Rozważania imperiologiczne, red. S. Bieleń, A. Skrzypek, Oficyna Wydawnicza ASPRA-JR, Warszawa 2015. 